\title{
The change of physical-chemical factors of the local interaction with the human body as the basis for the creation of materials with new properties
}

\author{
ALEKSANDR L. URAKOV - Izhevsk State Medical Academy, Izhevsk (Russia) - urakoval@live.ru \\ Érkezett: 2014. 12. 23. - Received: 23. 12. 2014. - http://dx.doi.org/10.14382/epitoanyag-jsbcm.2015.1
}

\begin{abstract}
The study of the dynamics of liquid, soft and hard tissues of the human body by physical contact for several minutes with vascular catheters, gastric, intestinal and pleural probes, tablets, and aqueous solutions of drugs subject to certain physical-chemical factors of loca interaction. It is shown that the interaction with these medical devices, the condition of the skin, subcutaneous fat, teeth enamel, established dental structures and mucous membranes of the oral cavity, esophagus, stomach, eyes, as well as the state of the venous blood inside the vessels within the vascular catheters and other devices for storing and injecting blood and infusion solutions, is largely determined by the preservation of the natural values of the physicalchemical characteristics of these tissues. It is established that medical devices, differing in their temperature, gas composition, osmotic and/or the acid activity of the relevant characteristics of body parts in contact with them, change their condition: the stronger, the greater the difference in their physical-chemical activity and the longer continuous interaction. In this regard, an assumption that the purposeful change of physical-chemical characteristics of the standard ("old") materials (in other words, the known substances) that underlie the production of products in solid and liquid state, allows us to get "new" structures and materials. It is shown that purposeful giving old materials new "old" materials with new physical and chemical properties and their use for the production of tablets and solutions from the "old" and well-known medicines can turn even very "old" medicines in very "young" (moreover, even very fashionable), and new drugs with unprecedented (even fantastic) pharmacological activity and with new mechanisms of action. Keywords: human, new materials, physical-chemical properties, mechanical properties, biological activity.
\end{abstract}

\section{Introduction}

Today's biotechnology progress leads to need for materials that retain their functional properties in various temperature regimes [1]. In addition, today there is a need to create new materials that are environmentally safe for the environment and for the human body. An example of the successful creation of materials and structures, safe to human body, can be tablets and solutions of drugs [2-8]. Most of the products available today often consist of excipients rather than chemical reagents. It is no secret that final pharmaceutical product is completely different from the pure chemical reagent, which was historically used for examining its toxicity in the beginning [9]. The matter is that pure chemical reagent is deliberately made very much polluted during the processing of tablets, solutions and sprays manufacturing [4]. Reagents are deliberately mixed with large amount of excipients and other substances. As a result, the medicine itself often has less than $1 \%$ of volume in the resulting mixture or solution which is used to prepare the final pharmaceutical product [4-5]. Our results show that physical and chemical factors local interaction of tablets and solutions with different parts of the body may be the basis of their therapeutic and local damaging effect on tissue $[10,14]$. It is also responsible for the development of medical iatrogenic diseases [8,9]. Moreover, it was established that the main cause of the local damage of drugs and medical devices is the difference in their physical and chemical properties [7].

\section{Materials and methods}

We have identified the most important physical-chemical characteristics of 200 quality medicines produced by pharmaceutical companies in the form of tablets and solution for injection. The quality of the drug was studied by taking into account the manufacturers and numbers of the series of medicines. Additionally, the specific Rockwell hardness (on a scale of Brinell, $\mathrm{HB}$ ) of the tablets were identified [15]. Evaluation of the quality of solutions of drugs was taken into account as their osmotic activity and the degree of saturation of the gas. Osmotic activity of aqueous solutions defined with cryoscope using vapor-pressure osmometer brand OSMOMAT-030 RS (production company ANSELMA Industries, Austria) [16]. Visualization of gas bubbles in carbonated solutions was held in visible spectrum of radiation on the eyes and ultrasound method using an ultrasound device ALOKA SSD-ALPHA 10 with a convection sensor of 3 to $7 \mathrm{MHz}$ frequency [17].

The peculiarities of the local interaction of the tablets in the oral cavity, esophagus and stomach have been studied in 
10 adult volunteers and in 10 waking piglets. The movement of the tablets in the cavity of the stomach was studied using ultrasound method. In 10 anesthetized cats the peculiarities of local interaction of the tablets inside the stomach have been studied after cutting of the stomach using surgical operations. For this purpose, tablets $0.1 \mathrm{~g}$ of ascorbic acid with glucose and/or tablets $0.5 \mathrm{~g}$ of calcium gluconate have been used.

Physical-chemical properties of 200 servings of venous blood, 300 veins limbs, 300 installed in them intravascular catheters and devices used for infusions was obtained of 200 patients admitted for treatment in Izhevsk Hospitals in the period from March 2008 to October 2014. In addition, the condition of blood in the great vessels and the subcutaneous veins of the injection site and catheterization veins in the wrist, forearm and shoulder of 10 corpses of adult patients died in the hospitals have been studied. Blood viscosity measurements were performed using a cone-plate viscometer Brookfield DVII, coagulation activity of the blood was studied by Lee-White, status of the lumen and the walls of the veins is studied in vena section, the state of the lumen of catheter in situ was studied on the eye, and with the help of the ultrasonic device Logik Book $\mathrm{XP}$, equipped with a linear transducer type 8L [17]. Rheology of pus was studied in 100 patients with purulent peritonitis, purulent conjunctivitis and tuberculosis of the lung and pleura. Rheology of pus was explored by the eye of in vivo and in vitro before and after the introduction in pus solutions of medicines with regard to the volume of interacting masses, the duration of their interaction, gravity, specific gravity (density), temperature, $\mathrm{pH}$ and osmotic activity. Pus was taken for analysis before and after 15 minutes after the start of its interaction with drugs [18].

The temperature dynamics of different parts of the body in 200 patients and in 100 healthy volunteers was studied by advanced infrared radiation with the help of thermal imager TH91XX (NEC, USA). Ambient temperature of the examination room was +24 to $+25^{\circ} \mathrm{C}$, the temperature window of the thermal camera was set to the range of +25 to $+36^{\circ} \mathrm{C}$ $[19,20]$.

\section{Results and discussion}

The results have shown that in real life there are no conditions under which the temperature of all body parts would be equal to $36.6^{\circ} \mathrm{C}$. The reality is that the temperature of various body parts of different patients can vary ranging from 0 to $+42^{\circ} \mathrm{C}$. At the same time Arrhenius and Van't Hoff proved that $10^{\circ} \mathrm{C}$ temperature difference can change the chemical reactions flow rate from 2 to 4 times.

It is shown that solutions of medicines entered to the body at room temperature (as a rule, at a temperature of +24 to $+26^{\circ} \mathrm{C}$ ). However, some solutions may be of lower or higher temperature, as part of the medicines specially cooled, as stored in refrigerator at a temperature of +4 to $+8^{\circ} \mathrm{C}$, and another part of the medicines is heated through ignorance, as is without temperature control temperature under the influence of heat sources (solar rays, infrared radiation from incandescent lamps and medical devices). In this regard, the intravenous introduction of Solutions for injections, performed by the conventional technology often changes the temperature of the blood, flowing inside the veins, which, in turn, changes the temperature of the venous wall and the tissues surrounding it, including the skin in the area of projection of subcutaneous veins. The phenomenon is called as thermo-contrast tissues and allows us to diagnose the localization of subcutaneous veins without X-ray contrast media and without physical contact with the body of the patient, due to the capabilities of infrared thermography of the skin (Fig. 1).
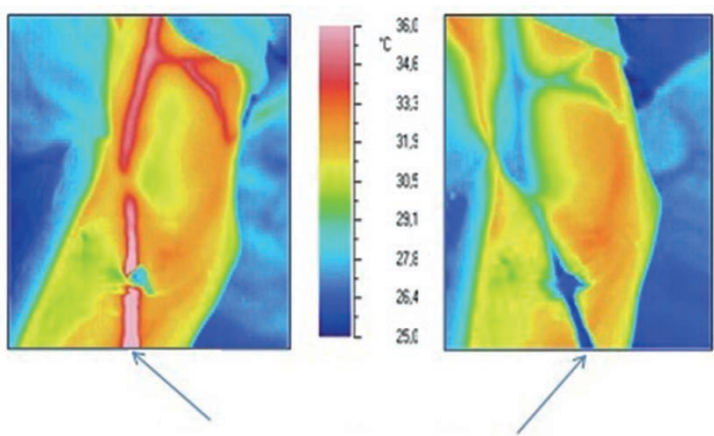

Intravascular catheter

Fig. 1. Visualization of intravascular catheter by infrared thermography

1. ábra Érkatéter kimutatása infravörös termográfiai módszerrel

Among other important and rather uncertain local interactions of physical and chemical factors are the duration, the specific pressure, the reduced specific gravity, $\mathrm{pH}$ (acidity or alkalinity), concentration, osmotic activity and gas saturation. It turned out that solutions of most drugs today are acidic, so after injection into a vein of acidic drugs can form blood clots in vein and appearance of the skin of limbs hearth of local hyperthermia above the end of the vascular catheter. However, a quick wash of the area of vein for 3 minutes with a warm solution of $4 \%$ sodium bicarbonate eliminates local hyperthermia in the place of location of the working end of the catheter and blockage of veins and catheter blood clots.

The results of the experiments have shown that a solution of $4 \%$ sodium bicarbonate is not able to completely dissolve all the dried blood, to destroy $100 \%$ of residual spots of blood for 1-4 minutes of interaction even at a temperature of $42^{\circ} \mathrm{C}$. In this regard, for the potentiation of hemolytic activity of this solution we decided to add hydrogen peroxide [21,22]. It turned out that aqueous solutions containing sodium bicarbonate and hydrogen peroxide in different ratios, get oxygenases, washing and whitening activity. Therefore, they can be used for saturation of venous blood with oxygen, to remove blood stains from clothes, to whitening bruises in the skin and to liquefy pus, lacrimal stones, sulfuric tubes etc. [2327]. The ability of hydrogen peroxide to saturate venous blood with oxygen was determined. The formula has been developed and patented a new quickening tool that represents hydrogen peroxide solution with osmotic activity of $280 \mathrm{mosmol} / \mathrm{l}$ of water and $\mathrm{pH}$ 7.4. This tool is intended to be injected into the portion of the venous blood, in order to saturate it with oxygen immediately before intravenous injection into the blood stream of the patient and increase the effectiveness of preventing hypoxic damage to the cortex of the brain [27]. 
The dynamics of color cotton-gauze swabs and skin, soaked venous blood in norm and after injection of solutions of drugs have been explored as well. Decolorizing activity of aqueous solutions of various chemical and medicinal substances with their concentrations in the range of $0.05-0.008 \%$ was investigated, at a temperature range of +20 to $+40^{\circ} \mathrm{C}$ and $\mathrm{pH}$ (alkalinity) range of 6.0 to $8.5 \mathrm{pH}$. It was revealed that the increase in $\mathrm{pH}$ above 7.4 , or heated above $37^{\circ} \mathrm{C}$ increases, and the decrease in $\mathrm{pH}$ below 7.4, or cooling below $37^{\circ} \mathrm{C}$ on the contrary reduces the ability of the solutions to discolor bloody tissues. It was found that at concentrations less than $0.05 \%$, the strongest decolorizing effect was attributed to hydrogen peroxide. The optimal composition of bleach solution ingredients, which form the basis of medicines called Bleach bruises has been determined [26].

It was shown that the rheological properties of thick pus and solutions of antiseptics and substitutes plasma at their local interaction depends mostly on conformity of volume and concentration, density, temperature, alkaline, osmotic and turbulent activity of medicines. The effect was studied by the following factors: gravity, specific gravity, temperature, turbulence, strength, internal pressure, carbonation, $\mathrm{pH}$, osmotic activity, total concentration of ingredients, surface activity and the amount of medication [29].

Our results showed that only alkalization decreases viscosity and dense microstructure of purulent masses. To check the value of high alkaline activity of the solutions, the rheology of thick pus was studied under the influence of such famous alkaline drugs like solutions of $4 \%$ and $10 \%$ sodium bicarbonate ( $\mathrm{pH} 8.0$ ) and solutions of $2.4 \%$ and $24 \%$ aminofillin ( $\mathrm{pH} 9.0$ and 12.0 , respectively). Results showed that at temperature of $24^{\circ} \mathrm{C}$ after $15 \mathrm{~min}$ of interaction of each of these solutions with thick pus, pus completely lost its viscosity and became liquid and very fluid. Solution of $10 \%$ sodium bicarbonate has the highest ability to dissolve thick pus. It was found that full liquefaction of pus occurred at a temperature of $24^{\circ} \mathrm{C}$ for $15 \mathrm{~min}$, at a temperature of $37^{\circ} \mathrm{C}$ for $12.5 \mathrm{~min}$, and at a temperature of $42^{\circ} \mathrm{C}$ for $12 \mathrm{~min}$ of interaction [30].

Consequently, the high density, high alkalinity and high osmotic activity, that is inherent in a solution of $4 \%$ sodium bicarbonate, ensures a high ability to dilute thick pus. In addition, as shown by the results, the ability of this solution to dissolve thick pus can be enhanced by high temperature and high turbulence. It is clear that the maximum permissible hyperthermia can be given to a solution by simply heating it up to $42^{\circ} \mathrm{C}$, but the maximum high turbulence needed to accelerate the process of liquefaction and dispersion of pus cannot be achieved by manual jiggle the capacity of interacting environments from side to side. Therefore, to provide a solution of maximum possible turbulence, it is decided to increase the concentration and the pressure of gases, in particular, due to carbon dioxide similarly to carbonated mineral water and due to the hydrogen peroxide. It is hypothesized that the high saturation by gas of the $4 \%$ sodium bicarbonate solution will have a powerful aggressive action on pus, because warm, heavy, alkaline and high osmotic action of solution is to be able to intensively penetrate into a pus and high saturation solution by gas and rapid formation of bubbles of carbon dioxide within a pus is to be able to blast it from the inside. To verify this assumption, initially a solution of $4 \%$ sodium bicarbonate was added in carbon dioxide under excessive pressure of 0.2 ATM [31].

It was found that high turbulence and high saturation by gas of warm solution of $4 \%$ sodium bicarbonate gives ability to effectively and safely dispose the pus out of purulent fistula in pancreatic necrosis.

It was also found that high saturation by carbon dioxide of solution $0.9 \%$ sodium chloride provides visualization using ultrasound vector direction and speed of movement of streams of a solution into the abdominal cavity is closed when it is flushed with the conditions of purulent peritonitis by identifying and monitoring of the movement of bubbles of carbon dioxide. In addition, it was shown that the visualization of ultrasound move process of gas bubbles in a moving solution of $0.9 \%$ sodium chloride in the abdominal cavity allows us to monitor and change the flow of a fluid due to changes in the location of the patient's torso in space together with a cavity. The point is that changing the location of the torso and abdomen in space allows us to change the direction of fluid in the abdominal cavity, necessary to wash better to the chosen location. The ultrasound provides visualization of the liquid move on the change of movement of gas bubbles [32].

Instead of the carbon dioxide, a solution of $4 \%$ sodium bicarbonate was added to $3 \%$ hydrogen peroxide as well. Then the activity of dilute pus of this solution has been studied when heated to a temperature of $42^{\circ} \mathrm{C}$ and introduction in the tube with pus. It turned out that infusion into a test tube with a thick pus equal amount of warm solution of $4 \%$ sodium bicarbonate and $3 \%$ hydrogen peroxide at a temperature of $42{ }^{\circ} \mathrm{C}$ leads to $5 \mathrm{~min}$ to the complete transformation of the two interacting environments in one turbid liquid with fluid properties [18].

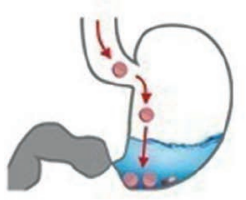

1

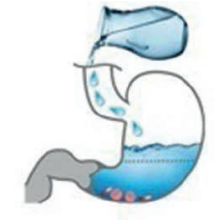

2

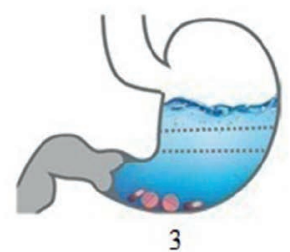

3

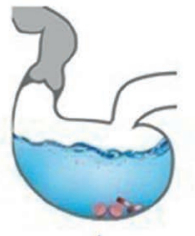

4

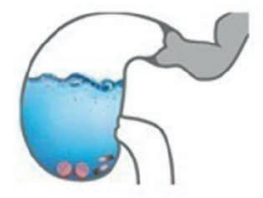

5
Fig. 2. Heavy tablets sink in gastric juice

2. ábra Nehéz tabletták lesüllyednek a gyomorfolyadékban

On the other hand, the physical-chemical characteristics of the tablets also affect the action of drugs when taking them inside. It turned out that the physical-chemical properties of modern tablets significantly differ in their physical-chemical properties of the tissues of the gastrointestinal tract. This difference is the reason of the local interaction of the tablets having a local physical-chemical effect on the tissues. It was 
found that all the tablets are very heavy (sink in water and gastric juice), many tablets are very solid, slowly decaying, very acidic and/or very salty (Fig. 2). However, it is unknown to the producers and consumers of drugs.

So today, due to the ignorance of doctors and patients, many pills may damage the enamel of the teeth, established dental designs, local burn of mucous membranes of the oral cavity, esophagus and stomach. There are a lot iatrogenic causes of pills such as damage by medical caries, medication, stomatitis, esophagitis, gastritis and ulcer pyloric stomach. At the same time, it is shown that the correct changes in the physicalchemical properties of the tablets can make them safe. In particular, we invented the easy (floating) tablet, which is a thick foam (Fig 3). This pill does not cause an ulcer in the pyloric stomach [33].

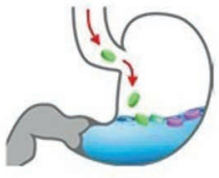

1

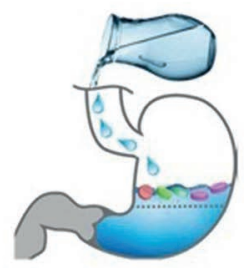

2

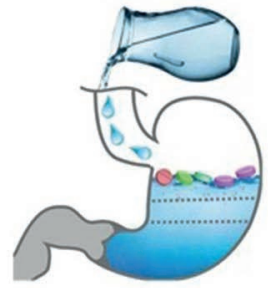

3
Fig. 3. Floating tablets do not sink in gastric juice

3. ábra Úszó tabletták nem süllyednek le a gyomorfolyadékban

Our data show that the values of specific deforming pressure pills now occupy the range from $0.03 \pm 0.0001 \mathrm{~N} / \mathrm{mm}^{2}$ (e.g. tablets Xefocam (lornoksikama $4 \mathrm{mg}$, Nycomed), $160 \pm 0.3 \mathrm{~N} /$ $\mathrm{mm}^{2}$; tablets Ketorol, Dr.Reddy's, India). In other words, all tablets have different hardness. Moreover, the value of specific deforming pressure of tablets can distinguish them from one another 5000 times. This is the reason why when tablets are chewed, some of them hurt the gums, lips, tongue, teeth, fillings, crowns, dentures, dental implants and braces. In this regard, we proposed to produce tablets only soft, and the value of specific deforming the hardness of the tablets should be included in a legitimate list of monitorable indicators for the quality of medicines [15].

It was found that rheology of liquid, viscous and dense biological tissues may improve medicines having the following physic-chemical characteristics: hypertermia, high alkaline, high turbulence and high saturation by gas. It was found that the leaders of improving rheology medicines and biological tissues are sodium bicarbonate, hydrogen peroxide and carbon dioxide, introduced in medicines similar to carbonated beverages. The data allowed to develop new hygienic medicines designed to liquefy thick purulent masses in patients with pleural empyema, peritonitis, rhinitis, sinusitis, conjunctivitis, tearful stones, osteomyelitis and sulfur tubes. New sanitary preparations are heated to $42^{\circ} \mathrm{C}$ aqueous solutions of 0.5 $10 \%$ sodium bicarbonate, of $0,5 \%-3 \%$ hydrogen peroxide and carbon dioxide, which is entered into the solution at a pressure of 0.2 ATM.

Open a new page in the pharmacology of drugs associated with the presence of gases: it is shown that the tablet is made in the form of a solid foam can float on the surface of the gastric juice, the solution representing the liquid foam can serve as an ultrasound contrast agent and the alkaline solution diluted hydrogen peroxide can whiten bruises in the skin.

And finally, it was discovered that hypoxia brain of the fetus can be defeated with intrauterine fetal lung ventilation respiratory gas with oxygen or by locally cooling the head of the fetus $[34,35]$.

\section{Conclusions}

The quality of medical products was shown that purposeful change of physical-chemical properties of hard, soft and/ or liquid materials from which they are made, by a certain amount in either direction from the physical-chemical characteristics of the tissues of the human body, physically in contact with them, capable of giving to these materials new properties, namely a certain biological activity, which, in turn, can determine their therapeutic or adverse effects. Therefore, development of new materials and structures with managed physical-chemical factors of the local interaction with the tissues of the body can be a promising strategy for the future development of environmentally friendly application and even healing items can be related to food, hygiene products, clothing, shoes, furniture, building materials and transport.

\section{References}

[1] Promakhov, V. V. - Buyakova, S. P. - Illiavszky, V. - Kulkov, S. N. - Gomze, L. A. (2014): Thermal expansion of oxide systems on the basis of $\mathrm{ZrO}_{2}$. Épitöanyag-JSBCM, Vol. 66, No. 3. pp. 81-83.

http://dx.doi.org/10.14382/epitoanyag-jsbcm.2014.15

[2] Urakov A. L. et al. (2007): Newton's Binomial as a "formula" development of medical pharmacology. Institute of Applied Mechanics Ural branch of the Russian Academy of Sciences, Izhevsk, $192 \mathrm{p}$.

[3] Urakov, A. L. - Urakova, N. A. - Yushkov, B. G. - Zabokrickiy, N. A. - Hausknecht, M. Y. (2011): Hypertermical, hypergazational and hyperalkalinical solutions as factors melting purulent activity. Bulletin of Ural Academy Medical Sciences, no. 1 (33), pp. 84-87.

[4] Urakov, A. L. - Urakova, N. A. - Kozlova, T. S. (2011): Local toxicity of drugs as an indicator of the likely aggressiveness of the local application. Bulletin of Ural Academy Medical Sciences, no. 1 (33), pp. 105-108.

[5] Urakov, A. L. - Urakova, N. A. (2012): After injection bruising, infiltrates, necrosis and abscesses can cause medicines because of the lack of control of their physical-chemical aggressiveness. Modern Problems of Science and Education, no. 5, pp. 5-7. http://www.science-education.ru/105-6812

[6] Urakov, A. L. - Urakova, N. A. (2014): Temperature of the site of injection in subjects with suspected "injection's disease". Thermology International, Vol. 24, no. 2, pp. 63-64.

[7] Urakov, A. L. - Nikityuk, D. B. - Urakova, N. A. - Soicher, M. I. - Soicher, M. G. - Reshetnikov, A. P. (2014): Species and dynamics of local skin injuries to patients in places, which are injections of drugs. Doctor, no. 7, pp. 56-60.

[8] Urakova, N. A. - Urakov, A. L. (2013): Colored mottling of the skin in the buttocks, thighs and arms of the patient as the page of history "injectable disease". Success of Modern Natural Science, no. 1, pp. 26-30.

[9] Urakova, N. A. - Urakov, A. L. (2013): Injecting a skin disease. Modern Problems of Science and Education, no. 1, pp. 19-23. http://www.science-education.ru/107-8171

[10] Urakov, A. L. (1987): Cold in protection of the heart. Science in the USSR. no. 2. pp. 63-65.

[11] Urakov, A. L. (1988): Recipe on the temperature. Udmurtia, Izhevsk, 80 p.

[12] Urakov, A. L. (1989): Recipe on the temperature. Science and Life, no. 9, pp. 38-42.

[13] Urakov, A. L. (2014): The history of the formation of thermofarmacology in Russia. The Success of Modern Natural Science. no. 12. pp. 29-39. 
[14] Urakov, A. L. - Urakova, N. A. (2013): Original hygiene for prevention of postoperative adhesions, efficient liquefaction of thick purulent masses, sulfuric tubes and tear stones. Modern Problems of Science and Education, no. 1. http://www.science-education.ru/107-7607

[15] Urakov, A. L. - Reshetnikov,A. P. (2014): Specific deforming the hardness of the tablets is another indicator of the quality of medicines. Success of Modern Natural Science, no. 9 (2), pp. 33-37.

[16] Urakov, A. - Urakova, N. - Kasatkin, A. - Chernova, L. (2014): Physicalchemical aggressiveness of solutions of medicines as a factor in the rheology of the dlood inside veins and catheters. Journal of Chemistry and Chemical Engineering, Vol. 8, no. 1, pp. 61-65.

[17] Urakov, A. L. - Kasatkin, A. A. - Urakova, T. V. (2014): Ultrasonic navigation as a way to control the movement of drugs within living tissues. Ultrasound and Functional Diagnostics, no. 4, pp. 61-65.

[18] Urakov, A. - Urakova, N. - Chernova, L. (2013): Possibility of dissolution and removal of thick pus due to the physical-chemical characteristics of the medicines. Journal of Materials Science and Engineering B, Vol. 3, no. 11, pp. 714-720.

[19] Urakova, N. A. - Urakov, A. L. (2014): Diagnosis of intrauterine newborn brain hypoxia using thermal imaging video. Biomedical Engineering, Vol. 48, no. 3, pp. 111-115. http://dx.doi.org/10.1007/s10527-014-9432-3

[20] Urakov, A. L. - Kasatkin, A. A. - Urakova, N. A. - Ammer, K. (2014): Infrared thermographic investigation of fingers and palms during and after application of cuff occlusion test in patients with hemorrhagic shock. Thermology International, Vol. 24, no. 1, pp. 5-10.

[21] Urakov, A. L. et al. (2012): Method and tool for removing earwax. Invention RU Patent $2468776 \mathrm{C} 2$

[22] Reshetnikov, A. P. et al. (2009): The method to express remove blood stains from clothes. Invention RU Patent $2371532 \mathrm{C} 2$

[23] Urakov, A. L. et al. (2009): Tool to thin thick and sticky pus. Invention RU Patent 2360685 C2

[24] Urakov, A. L., et al. (2010): The way the cubital vein catheterization and multiple intravenous injection of drugs. Invention RU Patent 2387465 C2

[25] Chereshnev, V. A. et al. (2008): Hyper-gazation and hyper-osmotic antiseptic. Invention RU Patent $2331441 \mathrm{C} 2$

[26] Urakov, A. L. - Urakova, N. A. - Chernova, L. V. - Fischer, E. L. (2014): Bleach bruises. Invention RU Patent 2539380 C2

[27] Urakov, A. L. et al. (2012): The way and means to remove sulphuric tube. Invention RU Patent 2468776 C2

[28] Urakov, A. L. et al. (2014): Hyperoxygenation tool E. M. Soicher for saturation of venous blood with oxygen. Invention RU Patent 2538662 C2

[29] Strelkov ,N. S. et al. (2007): Device for introducing an infusion solution. Invention RU Patent 2302266

[30] Strelkov, N. S. et al. (2002): The method of treatment of long-term psychological wounds. Invention RU Patent 2187287 C2
[31] Chereshnev, V. A. et al. (2008): Method of peritoneal dialysis from fizzy solution. Invention RU Patent $2336833 \mathrm{C} 2$

[32] Chereshnev, V. A. et al. (2008): Melting intestinal probe for newborn children. Invention RU Patent 2328319 C2

[33] Urakova, N. A. et al. (2005): Floating tablet. Invention RU Patent 2254121 C2

[34] Urakov, A. L. et al. (2012): Intrauterine scuba N.A.Urakova and method of ventilation of lungs respiratory gases. Application no. 2010134466. Inventions and utility models. Official Bulletin of the Federal service for intellectual property, patents and trademarks. No. 6. (1), pp. 38-39. http://www1.fips.ru/fips_serv1/fips_servlet

[35] Radzinsky, V. E. - Urakov, A. L. - Urakova, N. A. (2014): The way obstetric aid efforts. Invention RU Patent 2502485 C2

Ref.:

Urakov, Aleksandr L.: The change of physical-chemical factors of the local interaction with the human body as the basis for the creation of materials with new properties Épitőanyag - Journal of Silicate Based and Composite Materials, Vol. 67, No. 1 (2015), 2-6. p. http://dx.doi.org/10.14382/epitoanyag-jsbcm.2015.1

\section{A fiziko-kémiai jellemzők és az emberi test helyi kölcsönhatásainak jelentősége új típusú gyógyászati anyagok kifejlesztésében}

Lágy és kemény emberi szövetek és vaszkuláris katéterek, gyomor-, bél- és mellhártya szondák, tabletták vagy vízben oldott gyógyszerek fizikai kapcsolatának tanulmányozása a helyi kölcsönhatások egyes fiziko-kémiai jellemzôinek az ismeretét igényli. Bizonyított, hogy a helyi kölcsönhatások nagymértékben függnek a szövetek fiziko-kémiai jellemzôitốl, a vér transzfúziós és infúziós készülékek kapcsolata során. Az eszközök és anyagok hômérséklete, gáz tartalma és összetétele, kémhatása és ozmotikus aktivitása a legfontosabb befolyásoló tényezôk. Ebben a szemléletben a hagyományos eszközök és gyógyszerek múködési mechanizmusait célszerú új hatású, pl. nagyobb farmakológiai aktivitású vagy új mechanizmusokkal múködố eszközök és gyógyszerek fejlesztése irányában kutatni. A cikk rámutat az oldat koncentráció, a hômérséklet és a tabletták súrúségének jelentôségére az emberi szövettel történô helyi kölcsönhatásokban.

Kulcsszavak: humángyógyászat, új anyagok, fiziko-kémiai jellemzôk, mechanikai jellemzôk, biológiai aktivitás.

\section{MESSAGE FROM THE EDITORS}

The term composite is used to specify many different compounds at various practical applications. Use of silicate based and other inorganic composites provide experiences over millennia, since the prehistoric pottery technology of ancient civilisations up today's sophisticated pharmaceutical applications. The research in the biomedical field has been advanced enormously during the 21st century - continuing to remove the borders between scientific disciplines of materials research. Various composite materials including ceramics have been developed for drug delivery for example in human medicine. The selection of carrier materials for drug delivery needs special considerations, depending on the specific application and the specific targeted intake; bioactive, bioresorbable, and bioinductive composites are known for these purposes. Most advantageous applications usually combine organic and inorganic composites.

Építöanyag - Journal of Silicate Based and Composite Materials intends to promote a better understanding of ceramics and composite materials on a wide range within and beyond construction materials, provide a forum for recent advances in materials science and review the latest developments of sustainable materials. Aim of the journal is to serve as bridge between academic researchers in various fields of materials science, practicing engineers and designers as well as manufacturers and fabricators.

The Editorial Board is, therefore, proud to announce the first paper in the history of Épitőanyag - Journal of Silicate Based and Composite Materials that explicitly shows the interdisciplinary nature and the attention of the journal in breaking further walls between disciplines of materials research in the field of silicate based and other inorganic composites and invite our readers to enjoy the paper of Professor Aleksandr L. Urakov, MD about some results of the latest progress in biotechnology entitled "The change of physical-chemical factors of the local interaction with the human body as the basis for the creation of materials with new properties".

Assoc. Prof. Adorján Borosnyói Editor-in-Chief Építőanyag - JSBCM

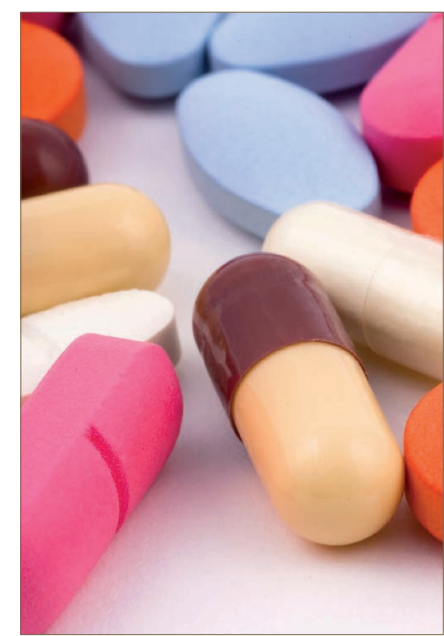

